\title{
Current Agricultural and Environmental Policies in Benin Republic
}

\author{
Ephrème D. Dayou ${ }^{1,2,5}$, Barnabé K. L. Zokpodo ${ }^{1}$, Marthe Montcho ${ }^{3}$, Emmanuel A. Ajav ${ }^{4}$, Isaac A. Bamgboye ${ }^{4}$ \\ \& Romain L. Glèlè Kakaî ${ }^{5}$ \\ ${ }^{1}$ School of Environmental Management, Faculty of Agronomic Sciences, University of Abomey-Calavi, 01 BP \\ 526 Cotonou, Benin Republic \\ ${ }^{2}$ Department of Environmental Management, Pan African University of Life and Earth Sciences Institute, \\ University of Ibadan, Ibadan, Nigeria \\ ${ }^{3}$ Laboratory of Applied Ecology, Faculty of Agronomic Sciences, University of Abomey-Calavi, 01 BP 526 \\ Cotonou, Benin Republic \\ ${ }^{4}$ Department of Agricultural and Environmental Engineering, Faculty of Technology, University of Ibadan, \\ Ibadan, Nigeria \\ ${ }^{5}$ Laboratory of Biomathematics and Forestry Estimations, Faculty of Agronomic Sciences, University of \\ Abomey-Calavi, 04 BP 1525 Cotonou, Benin Republic \\ Correspondence: Ephrème D. Dayou, School of Environmental Management, Faculty of Agronomic Sciences, \\ University of Abomey-Calavi, 01 BP 526 Cotonou, Benin Republic. E-mail: phreddoss1@yahoo.fr
}

Received: February 1, 2020 Accepted: March 26, 2020 Online Published: March 31, 2020

doi:10.5539/sar.v9n2p87 URL: https://doi.org/10.5539/sar.v9n2p87

\begin{abstract}
The need to feed the population growth conducts to the development of material intensive production systems in many countries. However the absence of adequate policies has adverse consequences on the environment and the performance of the agricultural and rural sectors. Benin Republic, through its Strategic Plan for Agricultural Sector Development (PSDSA) focuses on improving food and nutrition security, improving farm level income and building resilience to climate change within the Government Action Plan (PAG Bénin Révélé) 2016-2021. The aim of this study is to analyze the current agricultural policies and its link with the current environmental policies in Benin Republic. The data from Ministries and Structures in charge of Agriculture, Environment, Health and Human being were used. Reports from some international organizations such as FAO, PNUD and FIDA were also used. It is observed and planed an increase in cultivation area, all crops yields and crops production from 2016 to 2021. That will involve the more use of agricultural machinery, fertilizers and pesticides. Added to the current environment challenges, it appears the risk of soil degradation, deforestation, water and air pollution, then global impact on the environment when this plan will be implemented. It is right that some Environment Impact Assessment (EIA) are purposed for many of the actions. However, these EIA are sometime neglected and sacrificed for the profitability of agricultural production. To achieve this agricultural goal without affect the environment, the respect of the adequate law and EIA for each single activity becomes necessary.
\end{abstract}

Keywords: food production policy, natural resource management policy, environmental degradation, sustainable development, Benin Republic

\section{Introduction}

Sustainable agriculture integrates the goals of environmental health, economic profitability, and social and economic equity (ESCAP, 2009). The impact of agricultural policies on food security, poverty reduction and resource management is important. Looking forward, continued global population growth and changing demographic patterns, coupled with income growth will put increased pressure on food supplies and already scarce natural resources (Fan, 2010).

In some places, deforestation has been caused by the demand for new land for farming, building needs and timber harvesting and collection of non-tuber forest products; while erosion is caused by the farming systems adopted inappropriate road construction and maintenance methods associated with the farming systems. These practices and technologies impact on the productivity of the natural resources and purchased inputs used by farmers (MAEP, 2016). Depending on the management and productivity of agriculture's use of resources and 
inputs this will affect the rate of depletion and degradation of soils and water; the flows of harmful emissions into soils, water, air and the atmosphere; and the quantity and quality of plant and animal resources and landscape features.

In Benin Republic, the contribution of agriculture to the economy is not negligible. It currently employs $70 \%$ of the active population and $47 \%$ of the country's employment. Agriculture contribution to the gross domestic product has decreased from $33.1 \%$ in 1995 to $32.6 \%$ in 2005 and $25 \%$ in 2016 (World Bank, 2017). In order to improve the low productivity of agricultural work, the application of the agricultural modernization plan foresees changes in the cropping system in Benin such as widespread use of machines and fertilizers, large-scale exploitation of farmland and so forth (MAEP, 2017b).

To extend the cultivation areas and improve productivity, the mechanization of agriculture is a necessity (Beauval and Boquien, 2009). Thus, to achieve that objective, the Cooperatives for the Use of Agricultural Equipment (CUMA) were created. An Agricultural Mechanization Development Agency (ADMA) was set up to coordinate the development of the sector and a "BENIN TRACTOR" assembly center was also created, and these companies were closed down in 2016 and 2019 respectively. However, not only the problem of the compatibility of these imported agricultural machines with Benin's agro-climatic conditions was not studied (Zokpodo, Dahou, and Dayou, 2017), but also the environment considerations of these equipment were forgotten. The typical forms of agricultural related environmental degradation are deforestation, and soil erosion. The general impact includes loss of flora and fauna, decline surface and underground's water supply and food security. Through its emphasis on high production, the industrial model has degraded soil and water, reduced the biodiversity that is a key element to food security, increased our dependence on imported oil, and driven more and more acres into the hands of fewer and fewer farmers, crippling rural communities (Earles, 2005).

The impact of agricultural environment degradation frequently transcends the agricultural areas. To cure this, given the rainfall erosion observed in the Guinean zone in which Benin is located (Houndénou, 1999), special interest should be given to equipment and techniques that preserve water and soil. Sustainable agricultural policies on food security will undoubtedly depend on sustainable and productive resource base. Accordingly, therefore, the challenge today is how to increase productivity while enhancing the productive capacity of the natural resources base in sustainable manner. Benin is seeking to become an emerging economy by 2025 . To achieve this, it needs to manage the environment more efficiently in order to overcome the environmental challenges, facilitate sustainable development, and reduce poverty in the country (Banque mondiale, 2010). This paper analyzes the current agricultural and environmental policies in Benin Republic.

\section{Methodology}

\subsection{Study Area}

With an area of 114,763 $\mathrm{km}^{2}$ occupied by 11,496,140 people in 2018, Benin Republic in West Africa, is divided into 77 Municipalities and height (08) agro-ecological zones (Figure 1). The mean annual rainfall distribution of this country is ranged from $900 \mathrm{~mm}$ to $1300 \mathrm{~mm}$ with an annual temperature of 26 to $28^{\circ} \mathrm{C}$. The area situation promotes the growth of maize, cassava, cotton, palm tree, groundnut, beans... 


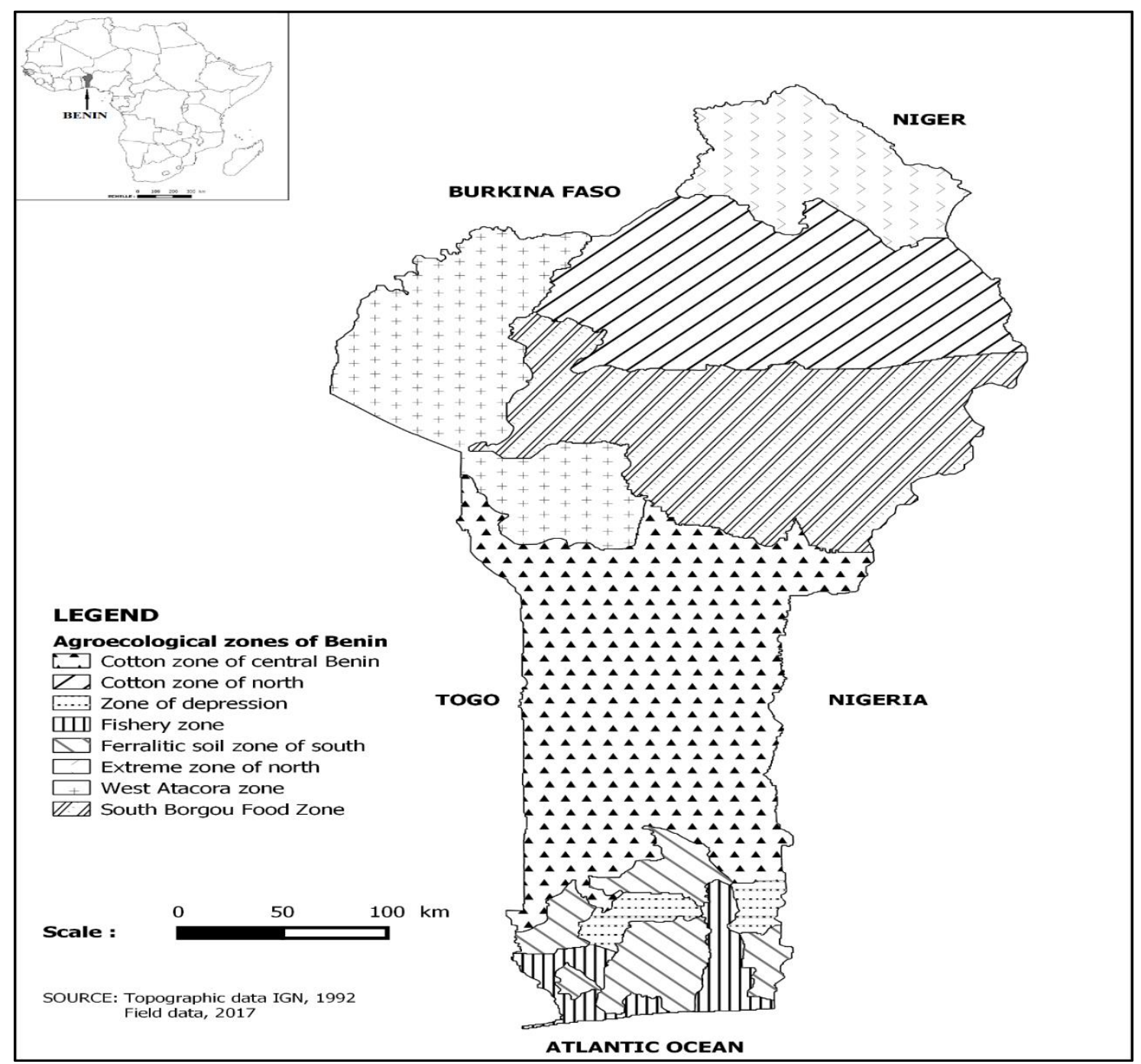

Figure 1. Location of study area

\subsection{Data Collection and Analysis}

Data were collected from Ministries and Structures in charge of Agriculture, Environment, Health and Human being. Reports from some international organizations such as FAO, UNDP and IFAD were also used. Among these documents, $89.65 \%$ are published between 2001 and 2018 and concerned land use policy, water use policy, forest exploitation policy, reducing carbon emissions policy, waste control policy and environmental impact assessment policy. Data obtained from the study were analyzed using descriptive statistics such as tables and charts.

\section{Results and Discussion}

\subsection{Strategic Plan for Agricultural Sector Development (PSDSA)}

The Government intends to modernize production tools and methods for the promotion of promising agricultural sectors through a large-scale investment in the agricultural sector to meet the three major challenges of 2021, namely: the coverage of food needs, increasing incomes, and improving the attractiveness of agricultural activity and rural areas. These three challenges give the agricultural sector the dual role of accelerating economic growth and contributing to poverty reduction. It is in this context that the government has developed its new Strategic Plan for Agricultural Sector Development (PSDSA) 2017-2025 (FAO, 2017).

The main objective of the PSDSA's vision is to improve the performance of Beninese agriculture, to enable it to ensure sustainable food sovereignty, food and nutritional security, and to contribute to economic and social development of men and women from Benin to achieve the Sustainable Development Goals. This overall goal is 
broken down into three Specific Objectives. First, it aims to strengthen the growth of the agricultural sector, food sovereignty and the food and nutritional security of the population, both men and women, through efficient production and sustainable management of farms managed by both men and women and young people. Secondly, to ensure competitiveness and access to agricultural production and agri-food products, including those produced by women and vulnerable groups, through the promotion of agricultural sectors. Finally, strengthen the resilience of vulnerable populations (men and women), particularly family farms (agriculture, livestock and fisheries / aquaculture sub-sectors) (MAEP, 2017a).

Through Decree No. 2016-681 (November 7, 2016) on the institutional framework of agricultural development, Benin has opted for the planning of agricultural development with the creation of seven (07) Poles of Agricultural Development (PAD) administered by Territorial Agencies of Agricultural Development (ATDA) whose role is to ensure the promotion of priority agricultural sectors by ensuring a better combination of the sector approach and the territorial approach as well as the application of instruments and related procedures. The Pole of Agricultural Development Plan (PADP) is the implementation of the Master Programs at the level of each Agricultural Development Pole. The PADP serves as a compass for ATDA interventions on their territory. It is developed under the technical coordination of the ATDA and serves as a basis for the development of the Sector Development Plans by pole.

Thus the Strategic Plan for Agricultural Sector Development is a part of the Goals of Sustainable Development. The analysis of table 1 allows to see the significant growth envisaged for the main crops.

Table 1 presents the corresponding performance indicators for the main crops of the intervention logic of the Agriculture Program.

Table 1. Growth rate of raw production of the main vegetable sectors

\begin{tabular}{lllllll}
\hline Crops & Reference values (T) & \multicolumn{7}{l}{ Target values (\%) } \\
\hline & 2015 & 2017 & 2018 & 2019 & 2020 & 2021 \\
\hline Maize & 1265348 & 5.02 & 7 & 7 & 9 & 8.60 \\
Rice & 216825.4 & 4.93 & 12.50 & 16 & 15.5 & 12.50 \\
Cassava & 3624919 & 5 & 7 & 7.50 & 10 & 10 \\
Cotton & 366489 & 23.41 & 16 & 17 & 16 & 14 \\
Cashew & 110761 & 14.26 & 12.50 & 12 & 12 & 12 \\
Pineapple & 291499 & 11.03 & 12 & 12.50 & 12 & 10 \\
Tomatoe & 288944 & 4.50 & 4.60 & 4.60 & 4.60 & 4.50 \\
Pepper & 65048 & 4.50 & 4.60 & 4.60 & 4.60 & 4.50 \\
Onion & 79204 & 4.50 & 4.60 & 4.60 & 4.60 & 4.50 \\
\hline
\end{tabular}

Note. $T=$ Ton

Source: MAEP, 2017a

In 2021, in terms of annual production, corn could increase with $42 \%$, rice to $78 \%$ and cassava to $46 \%$. Cotton production expected to increase to $106 \%$, cashew to $78 \%$ and pineapple to $63 \%$. Tomatoe will increase to $25 \%$, pepper to $25 \%$ and onion to $25 \%$. Some crops such as cotton may even surpass the double of their current production.

The figure 2 shows the increased of cultivatable land implied from the growth in production. 


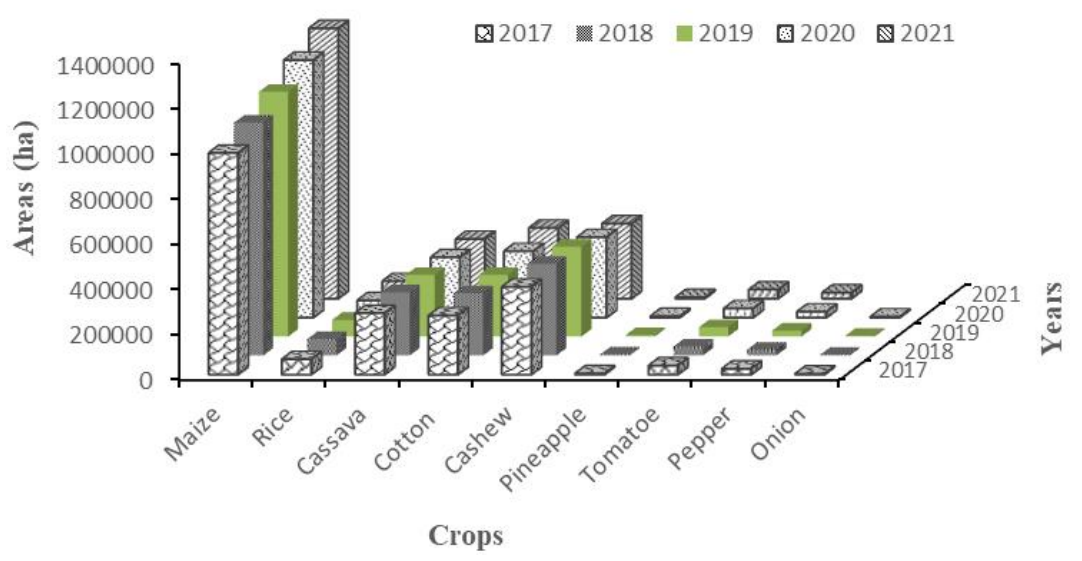

Figure 2. Numerical objectives of the areas to be planted for the principal vegetable productions

Source: MAEP, 2017b

It is observed an increase in cultivation area. Added to the increase of all crops yields, that will involve the use of machines and fertilizers. It appears the risk of soil degradation and pollution of the environment when this plan will be implemented.

It is therefore important for the agricultural engineers, environmental experts, soil scientists and all in charge of the implementation of PSRSA to seek for strategies to minimize the risk of environmental degradation (Gangnibo, Cheng, Huang, and Sambou, 2010). Within the framework of the PAG (Bénin Révélé) 2016-2021, the PSDSA and the accompanying PNIASAN focus particularly on improving food and nutrition security; improving farm level income; and building resilience to climate change.

The Environmental Unit created within the Ministry of Agriculture, Livestock and Fisheries in 2002 has since 2013 adopted an Action Plan to take into account the environmental dimension that serves as an instrument to farmers in the face of the dual need to improve agricultural productivity and preserve the environment. Finally, the Strategic Plan for the Development of the Agricultural Sector (PSDSA by 2025), successor to the PSRSA, has a strong orientation on the adaptation to climate change and takes into account the sustainable management of the resources and the resilience of the populations.

\subsection{Environmental Challenges in Benin}

Poverty and environment degradation are often related in many developing countries (WCED, 1987). It is known that the use of land for agricultural production is among the strongest factors affecting environmental quality (Zhang, Sui, Zhang, Meng, and Herbert, 2007; Oyekale, 2008). Despite of the acknowledged and important role of the environment in agricultural production for the economy, adequate attention is not often given to the proper use of the environment in order to realize maximum benefits.

Table 2 summarizes the environmental issues in the different agroecological zones of Benin and the proposed policies. 
Table 2. Environmental challenges in the different Agroecological Zones of Benin

\begin{tabular}{|c|c|}
\hline $\begin{array}{l}\text { Agroecological } \\
\text { zones }\end{array}$ & Environmental challenges \\
\hline $\begin{array}{l}\text { Zone } 1 \\
\text { Extreme } \\
\text { North-Bénin }\end{array}$ & $\begin{array}{l}\text { The processes of destruction of the flora and the disappearance of } \\
\text { the fauna are quite advanced. There is a trend towards soil } \\
\text { impoverishment and erosion, as well as the disappearance of } \\
\text { some species and plant species. Deforestation is done in } \\
\text { cultivated areas. Human activities have destroyed the ability to } \\
\text { reproduce and regenerate soil fertility. }\end{array}$ \\
\hline
\end{tabular}

Zone 2 : Cotton Zone of North Benin

Zone 3 : Northern Food Zone of Borgou

Zone 4 : West Atacora

Zone 5 : Cotton zone of central Benin

Zone 6 : There is a continuing degradation of the natural resources Ferralitic soil necessary for economic and cultural production (desertification zone of south

Zone 7 : Zone of depression

$\begin{array}{lll}\text { Zone } 8 & : & \text { It is observed the decline of vegetation, deforestation, soil } \\ \text { erosion, degradation and the reduction of fertility of cultivable }\end{array}$ Fishery zone soil degradation, reduced fertility of cropland and extensive degradation of vegetation cover. Human activities have destroyed the ability to reproduce and regenerate soil fertility. National and transboundary transhumance is a reality. Pollution of soils and streams by pesticides is observed.

Continued pressure on vegetation for agriculture and animal husbandry, and search for firewood, charcoal production, obsolete fishing and hunting practices, are drastically reducing vegetation cover. The result is a decline in vegetation, deforestation, soil erosion, degradation and reduced fertility of arable land. Agriculture is increasingly entering protected areas and marginal lands. National and transboundary transhumance has major disadvantages involving human lives. The high animal potential leads to overgrazing.

Agricultural production techniques have remained traditional with rudimentary practices. Agriculture is increasingly entering protected areas and marginal lands. National and transboundary transhumance explains the potential for high animal production. Food and water problems lead to overgrazing. Pollution of soils and streams by pesticides is especially noticeable in areas with extensive cotton cultivation.

Agriculture is increasingly entering protected areas and marginal lands. Cotton cultivation, which involves the massive felling of trees and bushfires, has led to severe soil erosion aggravated by sloping terrain, climatic hazards and transhumance. Pollution of soils and streams by pesticides, transboundary transhumance and overgrazing are noted. and deforestation, loss of biodiversity, soil erosion and impoverishment of cropland, etc.); the degradation of lake ecosystems: pollution, filling and siltation of water bodies.

There is a continuous degradation of the natural resources (desertification and deforestation, loss of biodiversity, depletion of agricultural land, etc.). Human activities have destroyed the ability to reproduce and regenerate soil fertility through the destruction of their surface. land. There is extensive degradation of wetlands and fisheries, degradation of lake ecosystems: pollution, filling and siltation of water bodies. Coastal management poses enormous environmental problems, including coastal erosion and saline intrusion in wet ecosystems.
Policy options

Support for integrated soil fertility and forest management

Regulate vegetation fires, establish transhumance corridors and promote organic pesticides.

Promote sustainable agricultural practices, reforestation and the establishment of transhumance corridors.

Define grazing areas, develop fodder crops, improve agricultural practices, promote organic pesticides

\section{Introduce}

community-based

management of

protected areas, promote

agro-ecology and environmental conservation practices.

Promote reforestation and integrated management of water and wetland

Support for integrated soil fertility management and erosion control

Regulate fishery, promote integrated management of water and wetland 
The analysis of Table 2 shows that, in spite of the other environmental issues specific to each zone, priority is given to the problems of soil degradation, soil and water pollution by pesticides and the degradation of vegetation cover that are common to all zones and therefore present throughout the country. These problems, which stem mainly from human activities with agriculture at the forefront, must be solved through an agricultural policy strictly guided by an adequate environmental policy.

\subsection{Environmental Policy: Legislative and Institutional Framework}

It was in the early 1990s that the environment began to become a major concern in Benin. This awareness has included the introduction of these issues into the constitution, followed by the adoption of Agenda 21, the Convention on Climate Change, Biodiversity and Combating Desertification to reach the Framework Law on the Environment in 1999. Article 27 of the Constitution of Benin that "Everyone has the right to a healthy, satisfying and sustainable environment and has the right to defend it. The Government takes care of the protection of the environment ". Benin has implemented a proactive environmental policy: Agenda 21, Environmental Action Plan, and National Environmental Management Program. The Poverty Reduction Strategy has been assessed from the perspective of integrating environmental aspects. Environmental management is also a cultural fact in Benin and even if these socio-cultural practices are disrupted, they remain a useful reference in the participative management of natural resources approach.

Benin's institutional framework for environmental management includes well-developed structures. In 1991, a ministerial department for the environment was set up, and after some restructuring, the Ministry of Environment and Protection of Nature (MEPN) was created. It relies on several structures, including technical directorates such as the General Direction of Environment (DGE), the General Direction of Forests and Natural Resources (DGFRN) and the Departmental Direction for the Environment and Protection of the Nature (DDEPN), as well as the bodies, offices and institutions under supervision. These include the Beninese Environmental Agency (ABE), the National Commission for Sustainable Development (CNDD), and the National Center for Wildlife Management (CENAGREF) and the National Environment Fund (FNE). With decentralization, initiated in the late 1990s, municipalities have acquired major competencies in the field of environmental management to strengthen local involvement and accountability for environmental concerns (Banque mondiale, 2010).

Benin has a detailed legal framework, which has grown considerably in the last 15 years. About ten texts of laws of legislation have been adopted, as well as numerous decrees and orders setting out their conditions of application. The implementation of numerous procedures and guidelines relating to environmental assessments, such as texts on water and air quality standards, wastewater discharge, various codes on public hygiene, forests, mines, regulations on the protection of the environment against dangerous substances etc., testify to a strong political will to put in place the regulatory and legal tools necessary for the sustainable development of Benin. Finally, besides this arsenal of texts, several guides have been written and edited by the Beninese Agency of Environment (ABE) for the benefit of those involved in the preservation and management of the environment in Benin (ABE, 2001, 2003, 2007). The regulations in force reflect Benin's obligations with regard to the international conventions that the country has signed.

The practice of Environment Impact Assessment has spread, leading to the development of a private sector of national consultants. For some sectors, Strategic Environmental Assessments are benchmark analyzed. Ownership of the results of these analyzes, however, remain to be worked on and the orientations contained in the Environmental and Social Management Plans are not always integrated during the implementation of the actions.

The regulatory framework has been enriched by a framework law on the environment, decrees and implementing decrees. Decentralization, begun in 2003 with the establishment of municipalities, provides for the transfer of skills to local communities, among which the environmental management aspects are numerous: waste, water, land. The distribution of roles between ministries and municipalities remains to be defined. The country is also a signatory to many international conventions. If all these legislative texts are coherent with each other, the question of their synergies (institutional, financial, ecological, and communicational) remains.

For the integration of environmental issues in thematic areas of intervention, efforts are still needed. The actual functioning of the environmental cells constitutes an axis. The definition and use of environmental governance tools (departmental dashboards, cross-cutting indicators) are important sources of progress room (Schlaifer, Doucouré, Lanmafankpotin, and Bertin, 2006).

The Environmental and Social Management Framework (ESMF) is designed as a sorting mechanism for the environmental and social impacts of investments and unknown activities prior to project appraisal. It is therefore an instrument for determining and evaluating potential future environmental and social impacts. In addition, the 
ESMF should define the monitoring and monitoring framework as well as the institutional arrangements to be made during the implementation of a project and the implementation of activities to mitigate adverse environmental and social impacts, remove or reduce them to acceptable levels (MAEP, 2016).

\subsection{View of Agricultural and Environmental Policies in Some Specific Areas}

\subsubsection{Land Use and Agricultural Mechanization Policy}

Inappropriate farming systems and technologies leave the soil worse off. Similarly, increased demand for livestock products has inevitably resulted in overgrazing. Within each path of the evolutionary process, a distinction is made between an expansion and an intensification phase. Systems driven by population forces alone increase food production by opening new land in the land expansion phase. When new land is no longer available, the intensification phase follows in which fallow periods are reduced (Igue, Floquet, and Stahr, 2000). Figure 3 shows the biodiversification policy in agricultural production in Benin. The Benin government introduced a Land Law project which was adopted by the National Assembly of Benin on the 14th of August, 2013 in order to regulate the land access all over the country. This law integrates land acquisition procedures, expropriation procedures, public utility land management, environment and natural resources preservation, land property rights, conflict management, and the administrative structure for land management. However, land use in Benin remains a huge challenge for the government (Ekpodessi and Nakamura, 2018).

As stated earlier, agricultural production derive its existence from the use of land. Without productive land resources, no meaningful agricultural activity can take off. Similarly, profitable crop and livestock production can thrive only if the elements of sunshine, water and soil nutrients, as well as plant nutrients contained in chemical fertilizers are present in the right proportion and quality. Furthermore, increased agricultural and industrial output thrives best where a conducive man-made socioeconomic environment exists. Natural resources must, therefore, be managed in ways to provide a basis for sustained development.

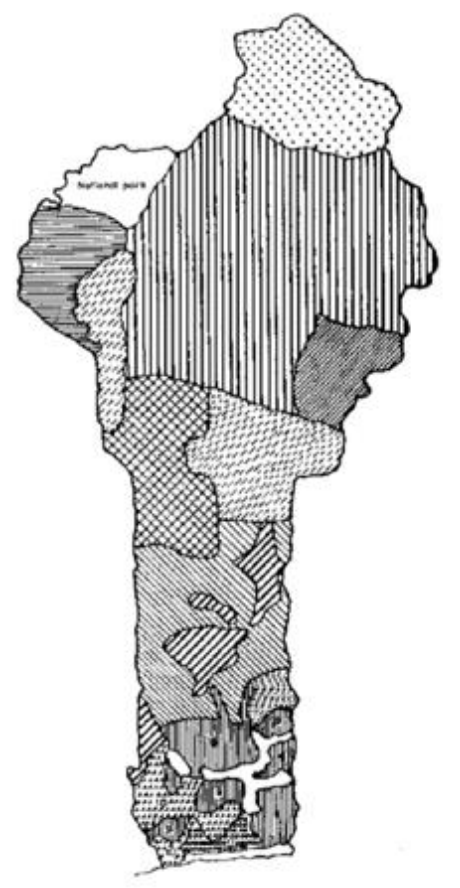

\begin{tabular}{|c|c|}
\hline$\because \because$ & Semiaridarea \\
\hline D & Cotton-based \\
\hline & Sorghum-based \\
\hline & Yam/Sorghum-based \\
\hline & Maize/Sorghum-based \\
\hline & Yam/Maize-based \\
\hline & Maize/Yam-based \\
\hline RiZl & Maize/Cassava-based \\
\hline 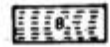 & Maize/Yam/Cassava-based \\
\hline : & Oil Palm-based \\
\hline 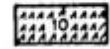 & Maize-based \\
\hline 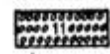 & Cassava-based \\
\hline 12 & Coconut-based \\
\hline
\end{tabular}

Figure 3. Global cropping systems in Benin (after Manyong, Smith, Weber, Jagtap, and Oyewole, 1999; Igué et al., 2000)

In many countries, projected population increases superimposed on exiting land holding pattern will result in an incredible increase in poverty derived pressure on the environment with accelerated erosion, deforestation and desertification along with continued loss of the genetic resources need to provide steady stream of new seed varieties. Land use coupled with the effort of small farmers is the key instruments for achieving sustainable increases in yield and productivity.

The Government of Benin planes the mechanization of adapted and accessible agricultural activities for men and 
women. With regard to the modernization of farm work tools, the focus will be on three key points: the revision of the National Strategy for Agricultural Mechanization and the operationalization of its institutional framework, the availability of adapted agricultural equipment through local production, import and distribution, maintenance and repair of agricultural equipment. It will also take into account the adapted agricultural mechanization during the implementation of the National Strategy for Agricultural and Rural Training (SNFAR). In terms of the availability of agricultural equipment, the approach aims to monitor, test and evaluate locally manufactured equipment for improvement, certification and extension, to compile labor standards for each category of material, to proceed subsequent techno-economic studies including environmental impact studies and promotion of agricultural and processing equipment and local manufacturers. It will also facilitate the acquisition of raw materials and imported parts for the manufacture of agricultural equipment at the local level and operationalize the assembly center of agricultural machinery. In terms of maintenance and repair, it will be necessary to provide specific training for craftsmen in the field of production and maintenance of agricultural equipment, develop local services and facilitate the acquisition of spare parts for imported material. (MAEP, 2017b).

Many studies have shown in Benin a close link between soil degradation and cultural practices (Igué, 2009; Olanrewaju, Gaiser, and Nuga, 2007). Resource policy planners have recently begun to recognize that many resource management systems embodied in the farming system that have persisted for years illustrate careful management of soil and water. In addition, such systems are an efficiency model and a regenerative approach to agriculture development. The principles underlying local management systems can be utilized to develop new techniques that will preserve the land's capability and productivity even as population increases.

\subsubsection{Water Use Policy}

Well watered as a whole, the country has relatively large water resources. Estimates of internal and external inputs amount to about 25 billion $\mathrm{m}^{3}$ per year, a quantity that is now sufficient to cover needs. This shelters it from any shortage for its socioeconomic development. The hydrographic network available to the country (very active in the rainy season) makes possible river and lake navigation for the transport of people and goods. But the increase in population is reducing the availability of resources per capita. Moreover, the quality of the water is deteriorating. Practices such as straying animals in water point protection areas, the presence of stagnant water, lack of control of drilling water, lack of wastewater collection and treatment facilities reduce natural quality of the resource. The hydro waste and related diseases are developing.

The water sector in Benin (resource management, drinking water supply and sanitation) is one of the area in which the effects on poverty reduction, improvement of living conditions and sustainable management of the environment are the most noticeable. Farming rely mostly on rainfall water and pesticides are present in almost all water around farms (Glin et al., 2016; Soclo et al., 2003)

In the face of the degradation of quality and the multiple uses of water, a systemic approach must be developed: supply of drinking water, water for food production (agriculture, livestock, fishing), water for other productive uses (industry, mining, transport, energy, crafts, tourism), water and health, water and natural hazards, water and culture - religion, water and natural spaces (biodiversity, tourism and outdoor activities).

The scarcity of resources leads to the illegal use of nets with too small mesh and the proliferation of prohibited fishing gear which causes the capture of fish below their size of first sexual maturity (more than $90 \%$ of the fish caught are immature). Added to this is the pollution of water by pesticides, urban and industrial effluents, and accidental spills of petroleum products transported by water, colonization of water bodies by water hyacinth, filling lakes and lagoons by erosion, change in the salt content of the lagoons.

The Law on water (Law No. 87-016 of 21 September 1987) in Benin Republic regulates the management of water and hydrological resources from a quantitative and qualitative point of view. It is supported by the quality standards for wastewater (Decree $n^{\circ}$ 2001-109 of 04/04/01) on the regulation of noise (Decree $n{ }^{\circ}$ 2001-294 of 08/08/01), waste management standards, solid waste management and management of used oils, Decree No. 2002-484 of 15 November 2002 on the rational management of biomedical waste and decrees regulating the issue of solid waste, waste materials and used oils.

In addition, the filling of waterways and watercourses poses a problem of availability of water resources and decreases the capacity for fisheries regeneration. There is also a general decline in water quality. The country is also facing coastal erosion and extensive degradation of wetlands and fisheries with the disappearance of the mangrove and the network of coastal lagoons with the loss of ecological habitats and extinction of living species, salinization and depletion of soils. The misuse of inputs for non-food sectors (cotton) by food crop producers (because they are very widely distributed and subsidized) generates significant pollution problems for groundwater and soil as well as human health (toxic residues pesticides in food, exposure of farmers who do not 
use protection and do not store products properly).

\subsubsection{Air Pollution Policy}

Environmental thinking affects all sectors of activity, from the most directly concerned (management of natural areas, agrarian systems, forestry and hunting management, livestock and fisheries, waste management, water supply) to less conventional sectors (health, industry, transport, spatial planning and urbanization). Others, such as tourism or crafts, are also part of the dynamic. Civil society (associations, NGOs) has seized the environmental theme along different axes: protection of wildlife and biodiversity, development process, support for rural and agricultural development including practices that are more respectful of the environment... This gives an interesting impetus in the emergence of initiatives and projects. Among the decrees aimed at standards relating to the living environment in the Republic of Benin, one could cite the decree $\mathrm{N}^{\circ}$ 2001-110 of April 04, 2001 fixing the norms of air quality in the Republic of Benin; Decree No. 2004-710 of 30 December 2004 imposing the obligation to import motor vehicles equipped with catalytic converters: CO: $0.50 \%$ and HC: 100 ppm. The effects of gases on the environment and human health are thus better and better understood, and some initiatives of measures are taken by the ministry in charge of the environment. Leaded gasoline has been banned since 2005. Since November 2005, Benin has switched to unleaded gasoline. An interministerial decree of November 23, 2004 also gives the characteristics of unleaded gasoline to be respected for any license holder importing, storing and distributing petroleum products and their derivatives. For the substances emitted, sulfur dioxide $\left(\mathrm{SO}_{2}\right)$, nitrogen oxides $\left(\mathrm{NO}_{\mathrm{x}}\right)$, nitrogen $\left(\mathrm{O}_{3}\right)$, carbon monoxide $(\mathrm{CO})$, atmospheric lead $(\mathrm{Pb})$, benzene The use of unleaded gasoline will not solve all air pollution problems. Carbonization in newly colonized forests is occurring in an uncontrolled manner to meet the energy demand of households that use $80 \%$ of fuel wood as a source of energy (FIDA, 2018).

\subsubsection{Pesticide and Plant Protection Products Use Policy}

In Benin Republic, its provisions concern the health protection of plants and plant products, through the prevention and control of harmful organisms both in terms of their introduction and that of their propagation on the national territory, with a view to safeguarding and guaranteeing a satisfactory environment conducive to sustainable development (Law No. 91-004 of 11 February 1991 on plant protection regulations).

The use of 'Endosulfan' pesticide in Benin was linked to significant health concern. 'Endosulfan' was widely used in cotton farming in Benin (Glin et al., 2006).

In the Strategic Plan for the Agricultural Sector Development, support is provided for the production and distribution of specific fertilizers and phytosanitary products for the priority vegetable sectors through the financing of the agricultural campaigns. It should allow the farmers to have the necessary availabilities at an early date for the adoption of improved inputs, promotion of information for better knowledge of inputs, support for the production of specific fertilizers and other biological inputs for sustainable management of soil fertility. The following support measures will be taken: support for research and extension structures for the development and transfer of technical specifications in terms of fertilization, phytosanitary treatments and storage, provision of the nomenclature approved at national level sub regional, regional and international actors in supply chains of inputs, professionalization of distributors through their training, certification and the structuring of their professional families, evaluation of the effects and impacts of inputs on the environment and taking mitigation measures and development and implementation of mitigation measures and promotion of biological inputs (MAEP, 2017b). Despite the number of decrees taken and the efforts made by the competent institutions, the pollution resulting from the mismanagement of plant protection products persists. Special attention should be paid to this law in the light of the speculations to be promoted with a view to minimizing the potential risks of certain inputs to be used. The development of a Pest and Pesticide Management Plan is required.

\subsubsection{Forest Exploitation Policy}

The typical forms of agriculture in Benin are deforestation, and soil erosion. Environmental management is also a cultural fact in Benin. Traditional power has since time immemorial developed usage rights and regulations to protect sacred sections of streams and various sacred forests. This traditional management is based on advice from elders, secret societies (Zangbeto), belief and fear of deities (vodoun), respect for the words of the elderly.

In few places, deforestation has been caused by the demand for new land for farming, building needs and timber harvesting and the collection of non-tuber forest products; while erosion is associated with the farming systems.

One of the most visible manifestations of environmental degradation is the decline in vegetation cover at the rate of 50000 ha of forest cleared per year for agriculture, livestock, and fuelwood requirements (FAO, 2014). Between 1990 and 2015 the forest area of the country has decreased by 25\% ; in 1990 the forests still occupied 
more than 50\% of the territory, this figure is only $38 \%$ in 2015 (FIDA, 2018).
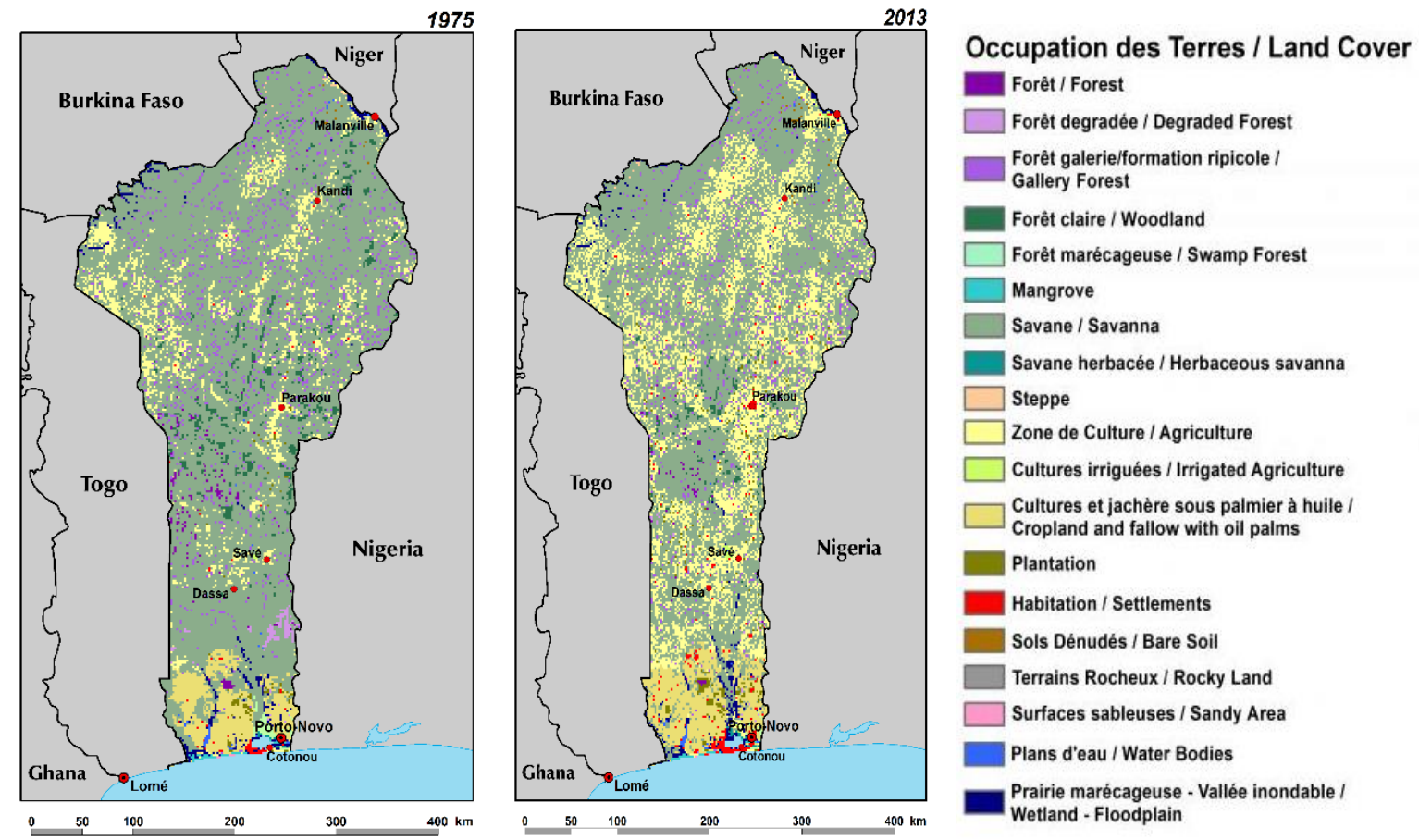

Figure 4. Evolution of land cover between 1975 and 2013

Source: USGS-EROS, 2016

After years of constraint-based forestry (sanction, fine, seizure), participatory forestry experiences exist in the country. They are committed to involving local people in the management of natural resources and contributing to local development. Methods of participatory management of forests and rangelands were implemented. At the same time, communal reforestation projects aim to help municipalities to manage and increase the forest resources.

Decree 82-435 prohibiting bushfires and plantation fires, Law 87-12 on the Forest Code of the Republic of Benin, Law 87-14 regulating the protection of nature and the exercise of the hunting, and other texts establishing the boundaries of the classified domain of the Government (classified forests, national parks, reforestation perimeters) constitute legislative provisions among other for the protection of forest and related resources. Law No. 93-009 of 02 July 1993 on the Forest Regime in the Republic of Benin, enacts the provisions on "management, protection, exploitation of forests, trade and industry of forest and related products". Article 11 contains one of the provisions favorable to the Project in that it states that "[...] the forests necessary [...] for the preservation of sites and the conservation of nature" may be classified. Moreover, Law No. 2002-016 of 18 October 2004 on the fauna regime in the Republic of Benin regulates the rational and participative management of wildlife and its habitats, the creation and management of protected areas, the protection of threatened, vulnerable or endemic species, and finally to offenses and sanctions.

So, the effects of agricultural environment degradation usually go beyond the agricultural areas. The general impact includes loss of flora and fauna, decline surface and underground's water supply and food security.

\subsubsection{Environmental Impact Assessment Policy}

Environmental assessment as an instrument for integrating environmental issues into decision-making processes is part of Benin's regulatory framework. The practice of Environmental Impact Assessment (EIA) has become widespread, it should concern all projects or developments likely to have environmental impacts. Real skills and know-how in this area are developed in the private sector. National consultants in environmental assessment and engineering meet the needs of the market. They are organized in association of reflections and professional exchanges. Strategic Environmental Assessments (SEAs) have been carried out for important sectors: energy, transport, livestock and textile. The reports are available and have been consulted. On the other hand, the results in the form of concrete action plans, are still being formulated. 
Benin Republic (Law 98-030 of February 12, 1999) operationalizes through environmental decrees the tools of environmental management (Environmental Impact Assessment, Strategic Environmental Assessment, Environmental Audit, Public Hearing on Environment) and national standards and standards for environmental quality under the technical coordination of the Benin Environmental Agency (ABE). Decree No. 2015-382 of 9 July 2015 on the organization of Environmental Assessment procedures in the Republic of Benin reinforces the previous texts. However, even if the EIA is setting up, taking into account the recommendations resulting therefrom often remains partial.

\section{Conclusion}

This paper has evaluated Benin's current agricultural policies in relation to environmental management policies in the country. It is noted that the Government plans to increase agricultural production through the extension of cultivation areas and improved yields of most food and cash crops. This involved setting up and using techniques and equipment that sometimes did not respect the environment. Thus, in order to achieve this goal of increasing agricultural production to achieve food security without affecting the environment, strict provisions must be made. Of course, management plans and environmental assessments are often included in projects. However, might must remain to their effective application.

For this, better monitoring and environmental precautions must be taken by giving priority to the most efficient technologies in the reconciliation of the environment and the economy. The formulation of Strategic Plan for Agricultural Sector Development must take into account the specifics of farmers and environment. That would allow to each person to make appropriate and commensurate contributions in maintaining environmental quality. The actual agroecological zonal arrangement of the National Farming Systems Research should be used in exchanging information and experiences. The relationships between climatic conditions, types of soil and management practices will be made available to rural development planners and farmers in order to let them know the soil characteristics, capabilities and limitations for different uses, agricultural practices suited to increased production and minimum environmental damage. Then, exchange of information in agriculture should be based on similar agroecological conditions. For deforestation, soil degradation, water and air pollution prevention, the training for land use under specific farming and grazing conditions, pest control, pesticides use and the forest exploitation must be highlighted.

\section{Acknowledgement}

This research was supported by the African Union through PAULESI.

\section{Conflict of interest}

Authors declare no conflict of interest.

\section{References}

Agence Béninoise pour l'Environnement (ABE). (2001). Guide général de réalisation d'une étude d'impact sur l'environnement. Agence Béninoise pour l'Environnement, février 2001, p. 76.

Agence Béninoise pour l'Environnement (ABE). (2003). Guide sectoriel d'étude d'impact sur l'environnement des projets d'agriculture. Agence Béninoise pour l'Environnement, p. 25.

Agence Béninoise pour l'Environnement (ABE). (2007). Guide Méthodologique pour l'intégration de l'Environnement et de la Durabilité dans la Stratégie pour la Réduction de la Pauvreté (SRP), Novembre 2007, p. 35 .

Banque, M. (2010). République du Bénin : Analyse Environnementale Pays. Département du Développement Durable, Région Afrique. Rapport Final 58190-BJ, Aôut 2010, p. 87.

Beauval, V., \& Boquien, N. (2009). Mécanisation dans le contexte africain : notions préliminaires sur les techniques et enjeux. Grain de sel, 48, 13-14.

Earles, R. (2005). Sustainable Agriculture: An Introduction. A Publication of ATTRA, the National Sustainable Agriculture Information Service, 1-800-346-9140-NCAT 2005 Edition Paul Williams, p. 8.

Ekpodessi, S. G. N., \& Nakamura, H. (2018). Land use and management in Benin Republic: An evaluation of the effectiveness of Land Law 2013-01. Land Use Policy, 78, 61-69. https://doi.org/10.1016/j.landusepol.2018.06.025

Fan, S. (2010). Achieving Sustainable Food Security: New Trends and Emerging Agenda. Multistakeholder Dialogue on Implementing Sustainable Development, United Nations Headquarters, New York.

FAO. (2014). Global Forest Resources Assessment - FRA 2015. Country Report, Benin. Rome. p. 85. 
FAO. (2017). Cadre de programmation pays du Benin 2017-2021. p. 19.

FIDA. (2018). République du Bénin: Programme d'options stratégiques pour le pays 2018-2022. EB 2018/123/R.5, 20 mars 2018, p. 82.

Gangnibo, C. N., Cheng, S., Huang, L., \& Sambou, A. (2010). Sustainable Agriculture in Benin: Strategies for Applying the Chinese Circular Agriculture Model. Journal of Sustainable Development, 3(1), 69-80. https://doi.org/10.5539/jsd.v3n1p69

Glin, L., Kuiseu, J., Thiam, A., Vodouhê, D., Dinham, B., \& Ferrigno, S. (2006). Living with Poison: Problems of Endosulfan in West African cotton growing systems. PAN UK. Published by Pesticide Action Network, London, UK, p. 48.

Houndénou, C. (1999).Variabilité climatique et maïsiculture en milieu tropical humide: exemple du Bénin, diagnostic et modélisation. Thèse de doctorat de géographie. UMR 5080, CNRS « climatologie de l'espace tropical », Université de Bourgogne, Centre de recherche de climatologie, p. 341.

Igué, A. M., Floquet, A., \& Stahr, K. (2000). Land use and farming systems in Benin. In: Adapted Farming in West Africa: Issues, Potentials and Perspectives. F. Graef, P. Lawrence and M. von Oppen (Editors), Stuttgart, Germany. p. 12.

Igué, A. M. (2009). Impact of Land Use on Chemical and Physical Soil Characteristics in Collines, Benin. Advances in GeoEcology, 40, 72-80.

MAEP (Ministère de l'Agriculture, de l'Elevage et de la Pêche), (2016). Projet d'Appui à la Diversification Agricole (PADA) : Cadre de Gestion Environnementale et Sociale (CGES). Version finale. p. 116.

MAEP (Ministère de l'Agriculture, de l'Elevage et de la Pêche), (2017a). Cadre programmatique du secteur agricole. Version validée. p. 154.

MAEP (Ministère de l'Agriculture, de l'Elevage et de la Pêche), (2017b). Plan Stratégique de Développement du Secteur Agricole (PSDSA) 2025 et Plan National d'Investissements Agricoles et de Sécurité Alimentaire et Nutritionnelle PNIASAN 2017-2021. Version finale. p. 139.

Manyong, V. M., Smith, J., Weber, G. K., Jagtap, S., \& Oyewole, B. (1996). Macrocharacterization of Agricultuiral Systems in West Africa: An Overview. RCMP Research monograph, 21, 66.

Olanrewaju, L., Gaiser, T., \& Nuga, B. (2007). Estimation of Potential Soil Losses on a regional Scale: A Case of Abomey-Bohicon Region. Benin Republic. Agricultural Journal, 2(1), 1-8.

Oyekale, A. S. (2008). Land Degradation, Soil Conservation Practices and Poverty Incidence in Southwestern Nigeria. Agricultural journal, 3(6), 482-487.

Schlaifer, M., Doucouré, D., Lanmafankpotin, G., \& Bertin, S. (2006). Profil Environnemental du Bénin. Rapport Final, Octobre 2006, Consortium COWI. p. 106.

Soclo, H. H., Azontonde, H. A., Dovonon, F. L., Djibril, R., \& Sagbo, U. A. (2003). Etude de l'impact de l'utilisation des engrais chimiques et des pesticides par les populations riveraines sur les écosystèmes (eaux de surface, végétaux et faune) des Aires Protégées (Parcs Nationaux et Zones Cynégétiques) du Bénin. Rapport final. p. 62-64.

United Nations Economic and Social Commission for Asia and the Pacific (ESCAP). (2009). Sustainable agriculture and food security in Asia and the pacific. p. 10-13.

USGS EROS. (2016). Land use, land cover and trends in Benin (West Africa). Retrieved from https://eros.usgs.gov/westafrica/land-cover/land-use-land-cover-and-trends-benin

World Bank. (2017). International development association project paper on a proposed additional credit to the Republic of Benin for the agricultural productivity and diversification project. p. 51.

World Commission on Environment and Development (WCED). (1987). Our common future-The Brundtland Report. Oxford: Oxford University Press.

Zhang, X. Y., Sui, X. Y., Zhang, X. D., Meng, K., \& Herbert, S. J. (2007). Spatial variability of nutrient properties in black soil of northeast China. Pedosphere, 17, 19-29. https://doi.org/10.1016/S1002-0160(07)60003-4

Zokpodo, B. K. L., Dahou, N. M., \& Dayou, E. D. (2017). Analyse des déterminants liés au fonctionnement des Centres d'Exploitation des Machines Agricoles (CEMA) au Bénin. Annales des sciences agronomiques, 21(2), 181-202. https://doi.org/10.1007/s40278-017-32860-x 


\section{Copyrights}

Copyright for this article is retained by the author(s), with first publication rights granted to the journal.

This is an open-access article distributed under the terms and conditions of the Creative Commons Attribution license (http://creativecommons.org/licenses/by/3.0/). 